\title{
TRIBAL MOVEMENTS IN INDIA: STRUCTURAL AND METHODOLOGICAL APPROACHES
}

\section{Mr. Soumitra Mondal}

\author{
Ph.D. Scholar, Department Of Educational Studies, Swami Vivekananda \\ Centre For Multidisciplinary Research In Educational Studies, A University \\ Of Calcutta Recognised Research Centre Of Ramakrishna Mission \\ Sikshanamandira (CTE) Belur Math, Howrah- 711202.
}

ABSTRACT Tribes have been recognised by historians as the first settlers of India. Equality and empowerment of Tribal people in India is ensured by the Indian Constitution and authorize the State to take constructive measures of discrimination for the good of Tribal people. This article critically examines Tribal condition in India, Tribal movements, various approaches to Tribal development, pre and post Independence Tribal situation, the Tribal development problems along the lines on social transformation and problems that Tribal development has to encounter. The main objective of this article is to motivate academics, writers, and educators in a new way of exploration in the process of Tribal studies, to impart awareness of various issues and concerns from postmodern Tribal perspectives.

KEYWORDS : Tribes, Tribal Condition, Tribal Identity, Tribal Movements, Tribal Development, Transformation.

\section{INTRODUCTION}

The Tribe is a colonial term developed by colonial authorities and ethnographers in the 19th century to identify all Indian groups. The definition of tribe was narrowed down to the primitive classes as distinct from castes. It was under the 1935 Govt. of India Act and the Constitution of India that the Scheduled Tribe nomenclature fully arose. A tribe is not specified by the constitution of India. People living in forests and on hills are administratively defined by the criterion of backwardness and remoteness. They are also known as adivasis - the natives.

\section{Primitive Tribes}

A total of 75 such groups were listed and classified as Primitive Tribal Groups (PTGs) in 17 states and one Union Territory. Major sections of these Tribes are small in size, have not achieved any meaningful level of social and economic development. J.J.Hutton first provided the term 'Primitive Tribes' for the Indian context. Four separate layers were observed by the Dheber Commission, among the most Backward Tribal Villages. At the lower rung, in an extremely under-developed point, the commission recognised a class of tribes. In 1975, a workshop on primitive tribal cultures was conducted as a first move. The topic was discussed in 1976 as the result of detailed guidelines for the identification of primitive tribal groups. The study team's recommendations were recognised by the Ministry of Home Affairs along with a clear demand for 100 per cent funding. Primitive tribes are made up of poor health conditions, depopulation, lack of education, widespread illiteracy, depending on hunting, forest, and old pattern agriculture, small and dilapidated housing conditions. Some of the primitive tribes' popular characteristics are that they have a Communalistic economic society pattern where each person's survival rests in common.

\section{Identity of Tribals in India}

Tribes have been recognised by historians as the first settlers of India. The Government of India does not recognise the ancestral status of the Tribes. Most tribal people consider the civilization of the Indus Valley to be one of the first examples of their origin.

\section{a. Territory}

The distribution of the Tribes on the physical map of India allows the classification of the tribes. The tribes in the regions below are: North and North-East, Central, Southern and Southern. The Andaman and Nicobar Island Tribes form the fourth regional classification, although geographically divided by waters, by being ethnically similar to the Southern Indian Tribes. b. Linguistic association

- Dravidian: Tamil, Telugu, Kannada, and Malayalam are the most developed Dravidian family languages.

- Austric: This speech in the family is often referred to as the Munda speech family.

- Tibeto-Chinese: These speeches are spoken by the Mongol Ethnic Tribes. Chinese-Siamese: spoken by North -East India Tribals.

\section{c. Ethnic characteristics}

With nine sub-types, the six key races list the most recent classification of The people of India. They are the Negrito, the Proto Australoid, the Mongoloid with the Mediterranean (Palaeo-Mediterranean, Mediterranean, Oriental type).

\section{d. Livelihood}

A detailed categorization based on the economic climate, such as hunting

Forest tribes, hilly farming tribes, cultivated land agriculture tribes, plain artisan tribes, pastoral tribes, folk artist tribes, agricultural and non-agricultural labour-oriented tribes, and service and trade tribes.

\section{e. Cultural acquaintance}

Tribes that are almost out of touch with outsiders and have a distinct culture; Tribes that have come into contact with outsiders with discomfort and problems; Tribes that have come into contact with other cultures but have not endured or been impacted.

\section{f. Spiritual Beliefs}

Most tribes follow their indigenous religion, but most are influenced by Hinduism, Christianity, Buddhism, Islam, Jainism, and others. Tribal societies are structured and retained by traditional law. Ritualistic rules from birth to death provide a humanitarian basis for their customs. The Tribes' experience and human technology help them survive side by side with flora and fauna.

\section{Tribal conditions}

Tribal problems are complex in nature and it would not be possible to solve them with one-time solutions. The first mission that politicians have to take on is to win the trust of the tribal people. The second task is to recover wealth, rebuild livelihoods and reaffirm the dignity of the Tribal people. Third is the administration's transparency, the depoliticisation of the National Commission on Scheduled Tribes and the functioning as a Tribal Tribune. The policies should see a transition in an evolving scenario. The backwardness of Tribal areas to some degree contributes to their geographical 
isolation. In the Tribal regions, there is scarce social and physical infrastructure. The system of forced labour and bonded labour was backed up by the Bonded Labour System (Abolition) Act, 1976. But it still prevails and Tribal communities are the easy target of it. There is no uniform Indian Tribal society in which all Indian Tribes will merge into a single mould. Tribesmen are distinct from Muslims, Christians, and Sikhs, but distinct from some Popular Hinduism type. Government of India's official stance is respectful of the values, traditions and way of life of the Tribes. Some state governments have shown that they are less susceptible to Traditional life habits. Grass-roots democracy has proved a bane to the tribes. The keys of the Panchayathi Raj system lie in the hands of the population's socially and economically influential sections. Indebtedness is a natural pattern for the life of Tribes. Defeat of land and forest rights, lack of availability of food grains, indifference, Expenditure beyond their means are some of the reasons for perennial indebtedness. An investment of Rs. 8000 per family would be necessary to help them to rise above the poverty line, according to the Working Group on the VIII Plan for the ST. The other issues related to the living style and suffering where the Tribes do not come out and are part of values, rituals of the vicious circle can be linked to the socio-cultural and biological component of de-population.

\section{Tribal Movements: Characteristics and Consequences}

Tribes have different traditions, social, economic and political forms of life as an ethnic group. Most of them are known farmers, so they consider their movements to be agrarian movements. Singh argues that the movements of peasants are only peasant movements because they live off land, while tribal movements are both agrarian and forestry because they depend on both for their lives. The focus of tribal movements has taken a turn towards the self-management of land, identity and ethnicity due to the rise in international indigenous movements. The increasing demand for the protection of the environment and related movements have influenced the essence of tribal movements, leading them to movements focused on identity. Based on the essence of their functioning, tribal movements have been categorised by various scholars in different ways. We can articulate them for conciseness as:

- Ethnic movements with inclusion of faith and culture

- Movements for agricultural and forest rights

- Environmental movements

- Unregulated movements of dislocation and rehabilitation - Political movements requesting a separate state.

Together with the formation of the British Empire, the first period of the Tribal revolutions was between 1795 and 1860 . The second period was from 1860 to 1920 , during which the Tribes, their land and forest were affected by Colonialism at its zenith, merchant capitalism. The third period was from 1920 to 1947, in which separatist movements for independence were led by the agitated Tribes. The Tribes and their headmen felt the loss of influence when the British conquered tribal kingdoms and founded their hegemony, and thus they came into conflict with the British. With the promise of bringing the earlier fortune back, many rebellious leaders led the movements. In Chotanagpur, the Birsa Munda Movement attacked Europeans, missionaries, officials and indigenous Christians. Konda Dora of Salur in the Vishakapatnam area, Naikda in Madhya Pradesh and Gujarat, rose against the British and Caste Hindus, though small in number. The fear of the Naga and some tribes was that, after Independence, they would lose their identity, ancient traditions and village organisations to the Hindu rulers. They thus demanded a separate state outside the Indian Union to safeguard the Naga society. There also began a new wave of political movement among the Khasis for fear of the Assamese control over them and disintegration.
Also known as the Sanskritisation movement, the Bhagat Movement was led to affirm the status of Tribes as Caste Hindus. Religiosity enabled the Tribes to combat exploitation with a code of political ethics. This movement stressed the development of a distinct state for the Bhils. Parts of Gujarat, Madhya Pradesh and Rajasthan saw a divide in the 1990s on the lines of conversion to militant Hindus and hatred for Muslims and Christians. The Tribal agrarian set up was different from that of the non-Tribal peasants.

But the invasion into the forest and hills of the non-Tribes not only abused the wealth of the Tribals, but also disrupted their organised economy. The Tribes lost their land to the money lenders and landlords in many parts, pushing them as tenants or mere workers to low status. Non-Tribal peasants were invited by the converted Hindu Chiefs to settle in Tribal areas and the latter occupied their land using the Tribes as staff. The land structure imposed by the British was distinct from their conventional system. Non-communal, feudal, zamindari or individual tenures replaced the Mundari system, custom replaced by contract, barter system by money leading to chaos leading to religious political movements of Birsa.

The forced labour and fight against the landlords in the Telengana movement was successfully led by the Andhra Pradesh Tribes. The Warli of Maharashtra worked in 1944 and 1946 demanding higher wages, both in agricultural and forestry work, and they led the revolt, unable to cope with the abusive landlords and bonded labour. The uprising against money lenders, landlords and liquor dealers was started in the 1920s by the Tribes of Western India. Later, in the 1950s, they declared non-revenue and land grab movements in Gujarat asserting their ownership of land. At the same time, Pardi Taluka initiated a campaign to introduce land reforms and the allocation of land to tillers under the competent leadership of the Socialist Party. The Tribes were the key elements of the Naxalbari movement that battled in the 1960s in West Bengal and Andhra Pradesh. The Bihar, Madhya Pradesh, Maharashtra, and Andhra tribes joined the land grab movement in 1969-70.

Ramapa Rebellion's main agenda was to oppose the toddy tax in Andhra Pradesh. To collect forest produce and timber from the forest the Kharwar of Palamau, Bihar, held the forest Satyagraha in 1930s and due to the persistence of the same issue they held the Satyagraha again in 1950s. In the 1930s and 1970s, the tribes of the Garhwal area struggled against forestry contractors. The Adivasis of the Dangs, Gujarat led the movements from the 1980s to the 1990s demanding the deprived soil and the right to harvest forest products without any fruits for their war. A number of tribes asked autonomous states or districts to administer their own tribal lives when they learned that newcomers to their culture were damaging them rather than justly governing them. As their goal was to establish their own Raj, pushing both Indians and British outsiders, the Kol uprising and the Santhal rebellion had a political face lift. Dang requested a district separate from the former bilingual state of Bombay. The Nagas in 1929, the Chota Nagpur tribes in 1938, the Gond tribe in the 1950s, the Mizos in 1960, called for their own separate administration. As one view points to 'Sub-nationalism' as the trait of Tribal movements on the basis of their language and religion, the other view calls it 'infra-nationalism' because Tribes advance from Tribalism to nationalism; it lifts the distinctness of Tribes from Tribalism to unification. Socio-cultural isolation from the rest of society, large population marked by economic stability, geographically closer to intercontinental boarders, leadership by education, politically defined peasantry responsive to inconsistency, prospect of political change with little chance of better off economy are the factors that are important for Tribal movement as follows. There are as many as 70 documented Tribal revolts but many a time without 
result. Discontent among the Tribes is growing day by day, and now the Tribal dwellings of the forests prove to be the home of Naxalites and extremists. Their challenge requires only physical and cultural survival and not development of higher skills.

\section{Approaches to Tribal Development Isolationist Approach}

In certain cases, the British government established 'excluded' and 'partially excluded' areas in order to keep the Tribes away from the common mainstream administration. The Government of India Act, 1870, denoting four 'Scheduled Tracts', incorporated this 'segregated isolationist' strategy. The new government, even after independence, was unable to eradicate the separatist policy that culminated in the formation of Nagaland.

\section{Assimilation Approach}

This approach explores the unification of the Tribes with those in society.

While some tribes have adopted Hinduism, others have pursued Christianity and various forms of tribes have thus arisen. Though classifying the Tribes, many writers such as Ghurye, Majumdar, Elwin, Dube said that assimilation for Indian scenarios is part and parcel of Tribal history and it is a herculean task to separate Tribes from being assimilated from the mainstream.

\section{Integration Approach}

Nehru's Pancha Sheela principles are

- Instead of forcing everything on them, Tribal traditional arts and culture should be encouraged to build up along the lines of their own intelligence.

- Tribal rights in land and forest should be respected.

- In addition to supporting the Tribes with technical support at the beginning, a team of their own people should be formed to do the administrative work.

- While they should not be devastated by a variety of schemes while controlling tribal areas, they should function in accordance with their social and cultural institutions.

Outcomes should be measured not in quantity, but in terms of the developed quality character of human beings.

\section{Political Approach}

This approach analyses the pre-independent and postindependent age with the

latter period enumerating general and specific safeguards for Tribes.

\section{Ådministrative Approach}

The President is responsible for safeguarding rules set out in the Constitution at the national level. Chief Minister and other Ministers assume responsibility for preparing and executing Tribal Welfare Schemes. Some States have independent Tribal Affairs Agencies, and other States have Agencies of Welfare. All these institutes, together with the Tribal Advisory Councils, assist in the development of tribal policies and programmes. The Parliamentary Committee on Scheduled Castes and Scheduled Tribes is influenced by the legislatures' influence.

\section{Religious Approach}

The Missionaries of religious denominations are actively making their presence felt in the Tribal based areas such as Bihar, Madhya Pradesh, Orissa, Meghalaya, Nagaland, and Mizoram through welfare activities and the propagation of religion. Critics indicate that if one's social unity is joined by a new faith, without alienating them from their brethren, and raising them to modern life, then it should not be opposed. If it disintegrates them, then only the tribal woes are applied to religious activities.

\section{Voluntary Agencies Approach}

After independence, the role of voluntary organisations emerged, promoting the introduction of welfare schemes by the government. The Government has also sought their assistance in recognising the issues of the Tribes, in order to introduce effective policies and programmes. It is noteworthy that the role of social workers as semi-officials is to propose suggestions and secure grants for tribes. While there are mushrooming organisations, some of the major organisations such as the Adimjati Sevak Sangh started in 1948; it is worth mentioning the Bharatiya Depressed Classes League, Servants of India Society, India Red Cross Society, All India Backward Class Federation and Indian Council for Child Welfare.

\section{Anthropological Approach}

As early as 1807, the Court of Directors of the East India Company ignited the knowledge of anthropology for better administration. Dr. Francis Buchanon was the first Governor General to begin the anthropology survey of the inhabitants of Bengal. To prepare books, gazetteers, monographs on Indian Tribes and castes, British officers were deputised. They believed in the Tribes' assimilation into Indian society's mainstream.

\section{Tribal Development in Pre-Independent India}

The Kol rebellion of 1831-32 led to the Muslims, Sikhs, and Hindus who had come as employers from other parts of India settling the Tribal land. The settlement and survey contributed to the Birsa Munda Movement in 1895. Money lenders and the merciless Landlords' tyranny caused the Santal rebellion in 1855 to be crushed only by the British rulers. The Sardari agitation of 1887 was served by forced labour, intermittent donations, unlawful enactment of rent by landlords. The mass conversion of the Tribals to Christianity on the assumption that they would be rescued by the Missionaries from the cruel landlords was among these problems. The British isolation policy was to keep the tribals away from any national movements as they realised their potential. The Tribal benevolent official Colonel Dalton graciously settled the dispute between Tundi's Zamindar and the Santals in 1869-70. The Madras Presidency Agency Tracts Interest and Land Transfer Act of 1917 were passed in 1917. The act had certain provisions. The first native Aborigines with whom the British interacted with were the Paharias or Malers of the Rajmahal hills. Sanad was assigned the mission of revealing all sorts of outbreaks to the representatives of these tribes. Retired and disabled soldiers were granted land at the foot of the hills, establishing a ring fence around the attacking Paharis. The lands were declared rent-free as a government estate, persuading the Pohariya Chiefs to join and acknowledge British rule. The Paharias were pacified by this tract known as 'Damane-koh' and the regulations were prepared as Regulation I of 1796. Between 1850 and 1890, the British Indian Government sent retaliatory expeditions to Assam, Nagaland, and Jaintia Hills, to Abor, Lushai and Naga Hills. The continuous deprivation and dissatisfaction of tribals led to separate and special arrangements to protect their lives and interests for isolated tribal regions. In 1874, an Act was passed to define Scheduled Districts; these fields were later reconstituted in Section 52A of the Government of India Act of 1919. In 1935, 'completely and Partly Exempt Areas' was incorporated for special treatment of Tribal areas.

\section{Post-Independence Period}

The rise of Tribal Freedom welfare was a dilemma to be noted and was expressed in the Constituent Assembly. The Constitution provided for the assimilation of the Tribals into the mainstream, making special provisions to preserve their cultures, although it continues to date for an initial duration of 
ten years. In 1951, along with Article 244 of the Constitution providing 'Scheduled Areas' and 'Tribal Areas' in accordance with the Fifth and Sixth Schedules, a Tribal Welfare Department came into existence.

States in which the Governor is granted powers to:

- In their state laws Application to them,

- Framework legislation to safeguard them and their property rights.

The Governor shall, in consultation with the Advisory Council of the Tribes in the State, formulate the rules at the same time. Two aims are fulfilled by these Scheduled Areas:

- To help the Tribals to enjoy their rights,

- To ensure the economic, educational and social development of the Scheduled Tribes.

An administrative division between the Centre and the States is envisaged in the Fifth Schedule. The government of the state seeks to frame and track laws for peace and good governance. It is the responsibility of States to enforce special schemes and general creation of tribes within their jurisdiction. The Government of the Union is directing the States with regard to the Tribal Administration and finding additional funds to improve their conditions. Policies and programmes are reviewed at annual conferences with the Planning Commission and the Ministry of Home Affairs.

The Customary Tribal Councils are the oldest Tribal structures with Tribal laws, religious rituals and social practises dealing with the social and religious problems of the Tribals. The introduction of the Panchayati system replaced the traditional Tribal Council with additional administrative, fiscal, and social responsibilities. Watching, warding, and regulation of fairs, markets, land, and health are the administrative roles. The economic functions include cottage industry production, animal husbandry, irrigation, agriculture, etc. whereas education, leisure, maternity, child care and so on are social roles. The numerous programmes related to the development of the Tribes are sponsored by the Central Government.

\section{Protective Provisions}

In addition to the Constitution, Article 15(4) provides for the State to make special arrangements for the progression of the representatives of the Scheduled Castes and Scheduled Tribes. Article 29 notes that, in order to conserve the language, dialect and cultures of minority groups, 15 per cent of the reservations should be provided by the aided institutions to SC and ST students. The provision is extremely necessary since most of them are bonded labourers under wretched conditions.

\section{Development Provisions}

Article 46 outlines the promotion of educational and economic interests of Scheduled Castes, Scheduled Tribes and other Weaker Sections. Article 275 provides financial assistance to the States to implement the terms made in the Constitution. Article 371-A (Nagaland), Article 371-B (Assam), Article 371-C (Manipur) provided for Special Provisions with respect to Tribal Areas and Hill Areas to the States.

\section{Reservation Provisions}

Under Article 332 of the Constitution, Article 330 guarantees the reservation of seats in the House of People and in the State Legislative Assemblies. Article 335 notes that the representations made by the representatives of the Scheduled Caste and Scheduled Tribe may be regarded as compatible with the preservation of efficiency.

Social transformation through Tribal development programmes

The three aspects of transformation in Tribal communities are
Politico-Social Transformation

With the dispute emerging from Chotanagpur and other regions, British people discovered that not everybody supported their scheme. The Tribals were saved by inaccessibility into the Tribal realm because forests were reserved long back from the $19^{\text {th }}$ century itself. The faster we move towards national development, the faster the urge for tribal growth leads to the utmost interference with tribal selfgovernance, writes Ravi Agrawal. The most detrimental impact of modern development plans would inevitably be to abandon the traditional political-social independence that the Tribals have cherished for centuries, he says. The writer is a member of the Indian National Congress.

\section{Economic Transformation}

Country has not seen any relative progress in this regard, and agriculture is proving to be the primary sector of the national economy. In the advent of emerging technology, the secondary sector sees little hope. Basic criteria should be clearly defined in order to update the planning in tribal communities where the task is diverse and complex.

\section{Cultural Transformation:}

In Tribal culture, there is no one rich or no one poor, and that is the agreed Tribal society structure. They hold land in common, but the administrative credit is granted only to individual possession. In Rourkela, when new industrial complexes on the Tribal land were established, this situation is reflected. In this case, the administration has turned out to be the intruder of Tribal land. The oral tradition is familiar to the Tribals and sacred to them and they stand by the word. The modern system operates essentially only through the formal system and the document system. The Tribals are not conscious of the worth of money and their entrance has destroyed their innocence. The administration should see that the reform process should not lose the command of the Tribal over their land. In relation to the administration of their everyday affairs, the current democratic decentralisation does not respect the authority of the tribes. New institutional structures, with which the Tribes are unable to reconcile, are undermining traditional self-governance bit by bit.

\section{Problems of Tribal Development}

Tribals have been put in a position to embrace acute poverty and destruction by the inhumane apparatus of the developed world. The principle here is to not ignore the initiative of India towards the Tribals, but to balance modernity and sensitivity towards Tribals. Constitutional guarantees are irrelevant to the concepts of equity and justice, unless they are considered from the point of view of the lowest range of society in which Scheduled Tribes belong. The only concern of the modern sector is to maintain power and place to step towards the high tide of growth. Land as a natural resource is the foundation of people's lives, although it remains unchanged in legal form, excluded from the list of fundamental rights. Agricultural labour, the most professional and the most difficult, was considered to be unskilled. This is the reality of all kinds of work that contributes to deprivation and exploitation in the unorganised market. The situation has led to the death of selfrespect and integrity that they are aware of, the psychological state of embracing misery and destitution. The denial of the right to land causes the Tribals to combat the regime. Tribals are not permitted to have access to their resources in the name of protecting the woods. All land issues are addressed without any hope of justice in courts outside their territory. Instead of breaking the shackles of bonded labour, the strategy regarding bonded labour cuts the Tribes from their life support.

Although the pressure on forest has increased, it is true that a Tribal has not built mansions out of it in any way. If tribals can be provided with alternative livelihoods, the shifting 
cultivation by clearing the forest is done under compulsion for their livelihood, they would welcome it. Development has gone through a critical stage in transforming the tribal lands into a modern system of forests, hills or agricultural land. The law recognises only owners of wealth and not shareholders, daily wage earners, shepherds, hunters, etc.

\section{CONCLUSION}

Tribal movements are now defined as identity-based movements, the only repercussions of which are numerous other issues relating to sovereignty, property, forest, language and scripts. It is identity that is being stressed. At the centrestage, personality stands. This shift in perspective has now been made possible by people's own perceptions of the situation, their perspective of their culture being gradually challenged, the current movements of the environment and indigenous people, etc. The tribal movements are now put in the sense of power relations, the scramble for power, the quest for equations within an area between different groups. Like other cultures, the tribes have developed as political communities. It is no longer considered that tribal movements belong to one type. The movements that emerge from dynamic social conditions are viewed as a mixture of forms and characteristics. So are the causes and procedures that are now considered to be endogenous and exogenous, a mixture of capital, culture and identity problems.

\section{REFERENCES}

1. Singh, Kumar S 2002. People of India: introduction. New Delhi: OxfordUniversity Press.

2. Toppo, S.R. 2000. Tribes in India. Delhi: Indian Publishers Distributors

3. Singh, Rajendra. 2001. Social Movements, Old and New: A post-modernist critique. New Delhi: Sage Publications.

4. Patel, M.L. 1994. Tribal Research in India: Approach, Constraints, Structure and Techniques. New Delhi: Inter India Publications.

5. Kamei, Gangmumei. 2004. A history of the Zeliangrong Nagas: From Makhel to Rani Gaidinliu. Guwahati: Spectrum Publications.

6. Srinivas, M. N. 1995. Social change in modern India. Hyderabad: Orient Black Swan.

7. Haimendorf, C. V. F. 1987. Tribes of India: The struggle for survival. New Delhi: Oxford University Press.

8. Rupavath, R. 2009. Tribal land alienation and political movements: Socio economic patterns from South India. Newcastle upon Tyne: Cambridge Scholars Publishing.

9. Rao, M. S. A. eds. 2006. Social movements in India: Studies in peasant, backward classes, sectarian, tribal and women's movements. New Delhi: Manohar

10. Das, Veena and Deborah Poole 2004. State and Its Margins: Comparative Ethnographies. In Das, Veena and Deborah Poole, eds. Anthropology in the Margins of the State.Santa Fe:School ofAmerican Research Press, pp. 3-34.

11. Wilson, Geoffrey., and Wilson, Monica. H. 1945. The Analysis of

12. Social Change, Based on observations in Central Africa. Cambridge: Cambridge University Press.

13. Ghurye, G.S. 1963 (3rd edition). The Scheduled Tribes. Bombay: Popular Prakashan.

14. Government of India. 1984. Report of the commission for Scheduled Castes and Scheduled Tribes (1984), sixth report, April 1983-March 1984. New Delhi: Author. 